\title{
The Effect of One Session Acute Exercise on the Urinary Excretion of Urinary Gamma-Glutamyl Transferase, Protein and Creatinine Levels of Elite Football Players
}

\author{
Ramtin Azar ${ }^{1} \&$ Paria Majidi² \\ ${ }^{1}$ Department of Oral and maxillofacial Radiology, School of Dentistry, Tehran university of Medical Science, \\ Tehran, Iran \\ ${ }^{2}$ Physical Education and Sport Sciences, Islamic Azad University, Central Tehran Branch, Tehran, Iran \\ Correspondence: Ramtin Azar, Department of Oral and maxillofacial Radiology, School of Dentistry, Tehran \\ university of Medical Science, Tehran, Iran. E-mail: dr.ramtinazar@gmail.com
}

Received: December 10, 2019

Accepted: January 21, 2020

Online Published: March 30, 2020

doi:10.5539/jmbr.v10n1p46

URL: https://doi.org/10.5539/jmbr.v10n1p46

\begin{abstract}
The aim of the present study was to evaluate the effect of one session acute exercise on the urinary excretion of urinary Gamma-glutamyl transferase, protein and creatinine levels in elite football players. A total of 30 Premier League football players with a mean age $(26.1 \pm 3.80)$, a mean height $(180.01 \pm 7.39)$, a mean weight $(78.6 \pm$ $9.26)$ and a mean body mass index $(24.87 \pm 1.13)$ were voluntarily and purposefully selected as statistical samples. The urinary sample of the players was collected in two stages. In the first stage, the players' urinary samples were taken on the rest day when they had not exercised for 24 hours. In the second stage, it was taken immediately after exercise and transferred to the laboratory. To test the hypotheses, especially to compare urinary protein, creatinine, and gamma-glutamyl transferase levels before and after exercise, and to compare excretion levels of protein, creatinine, and gamma-glutamyl transferase between the positions, ANOVA test was used. There was a significant difference between the levels of gamma-glutamyl transferase, proteinuria and creatinine before and after exercise $(\mathrm{P}<0.001)$. There was a significant difference between the results of level of excretion of protein, creatinine and gamma-glutamyl transferase among different positions $(\mathrm{P}<0.001)$. In addition, LSD post hoc test was used to compare the pairwise scores of the variables among the positions.

In general, the results of numerous studies suggested that long-term and high-intensity exercise increases the levels of urinary protein and creatinine more than normal level. If it continues for a long time, it can cause irreparable injury to the kidney tissue. In addition, it seems that gamma-glutamyl transferase enzyme can be more affected by exercise intensity and events of exercise and competition.
\end{abstract}

Keywords: Gamma-Glutamyl Transferase, Protein, Urine, Creatinine

\section{Introduction}

Physical activity is extensively constructive for every single individual (Ibrahim et al., 2018). Resisted exercise is effective in optimal health (Mady et al., 2018). Physical activities affect different body systems and lead to their adaptation to the specific needs of the organs during physical activity. Muscles, cardiovascular systems, respiratory system, kidneys are the organs whose function changes during physical activity. Components of physical activity arlead to cardiorespiratory fitness, muscle strength, flexibility, agility, and muscle endurance (Zaeimi Fard et al., 2017). The kidneys are vital organs that are important in controlling volume, osmotic pressure, electrolyte content, and the stability of the internal environment of the body. Thus, it is not surprising that kidney dysfunction affects almost the function of other body systems. Hence, recognizing the interactions between exercise and the kidneys is crucial to fully understanding how physical activity works. Recognizing these two effects is also important for recognizing their control mechanisms for designing and setting exercise programs and the type of exercise activity. Exercises can cause dramatic changes in renal hemodynamics and electrolytes.

Various factors are involved in the occurrence of these renal hemodynamic changes, one of which is ischemia, caused by the redistribution of blood during exercise and its abnormal circulation to the active muscles (Poortman, 1984). Based on the results of the Poortman et al. (1988), reduced kidney blood flow is accompanied 
by narrowing of the arteries by epinephrine and norepinephrine hormones during exercise, which can have continuous effects on the ratio of filtration. In this regard, lack of using fluids during exercise can reduce the kidney blood flow below the normal level and reduced glomerular filtration rate can cause acute tubular necrosis (Harman et al., 2003). Investigation of urinary proteinuria, creatinine and gamma-glutamyl transferase enzymes play major roles in the prognosis of kidney tissue injury. Studies conducted in recent years have shown that an increase in these three indices after prolonged and high-intensity exercise can be a sign of injury to the parts of the kidney tissue. Ayca et al. (2006) in a study on 12 male and 12 female Volleyball players showed that urinary creatinine and protein increased in male players. However, only urinary protein increased significantly in female players. In this article, the level of excretion of urinary gamma-glutamyl transferase enzyme increased only in male spiker players after exercise and this difference was significant, while there was no significant difference in other positions. Ayca attributes this increase to gamma-glutamyl transferase caused by high-intensity exercise and jumps in spiker players. In 2003, Turgut studied the effects of exercise on protein, insulin-like growth factor IGF1 and insulin-like growth factor-binding factor (IGFB-3) in the urine of volleyball players. Results of the study showed significant increase in urinary protein and creatinine and IGF, while significant increase was not seen in IGFB-3.

Nowadays, one of the most important concerns of professional athletes who get engaged in various sports activities is the possibility of various disorders and failures in various body systems, including immune, respiratory, renal systems, etc. Numerous uncertainties with regard to kidney function during exercise require conducting further research to answer existing questions. Football game requires the ability to withstand over 90 minutes of varied and high-intensity physical effort. Nowadays, professional football players travel an average of 10 kilometers in a match, whose $90 \%$ of consumed energy is supplied by aerobic metabolism. Moreover, unlike most sports, football players often have to participate in different club or national competitions 2 or even 3 times a week and repeat exercise sessions, because lack of receiving adequate energy put the player at the risk of reduced performance and kidney injury (Bangsbo, 1991).

Although it has been stated that exercise have beneficial effects on people's health, research findings in recent years have shown that professional exercise and consequently heavy and continuous exercises can cause problems for professional athletes. Repeated high-intensity exercise sessions, reduced kidney blood flow, poor recovery, dehydration, and the blows imposed on the athlete are some of the factors that can cause kidney tissue injury in professional athletes (Poortmans et al., 1988). Kidney tissue injury is associated with physiological symptoms. These physiological indicators change based on the exercise pressures. The kidneys are responsible for clearing some of the waste and toxins caused by metabolism. Kidney function tests evaluate the excretion power of these substances by the kidney. To measure kidney excretion power, the concentration of certain substances in the blood and urine is often measured. In this regard, changes in urinary excretion of creatinine, protein, gamma-glutamyl transferase play a major role in the prognosis of kidney tissue injury. If the urinary excretion of these three indicators increases after the exercise, it can be stated that the kidney tissue of athletes are at risk of injury. One of the most important symptoms that indicate kidney injury or disease is increased protein excretion in the urine after exercise or proteinuria. The level of protein secreted in the urine has clinically high importance (Dilena, 1983).

The term "proteinuria" is an indicator that indicates urinary protein excretion is higher than normal level. The normal level of proteinuria in healthy individuals is $150 \mathrm{mg} /$ day or $10 \mathrm{mg} /$ liter (Bergstein, 1999). Two major mechanisms can cause proteinuria, including increased glomerular secretion with no change in tubular reabsorption and defects in the reabsorption of filtered protein from tubular (Poortmans, 1985). Proteinuria is a term indicating that urinary protein is excreted above normal level. Increased protein excretion can be a result of increased glomerular permeability and defect in tubular reabsorption of plasma proteins (Poortmans, 1985). Factors such as changes in the hormonal system, reduced kidney blood flow, dehydration, and reduced glomerular electrostatic barrier cause proteinuria. Therefore, excessive protein excretion in urine after high-intensity and prolonged activity is a sign of impaired kidney tissue. Acute kidney failure is a syndrome that can be defined as a sudden reduction in kidney function leading into the retention of nitrogenous waste materials (such as nitrogen, blood urea, and creatinine) in the body. Urinary creatinine is a byproduct of the degradation of creatine and phosphocreatine, found more in muscles. It turns into creatinine with loss of water and flows into bloodstream. Kidneys also excrete it through urine. Its excretion is relatively stable under normal conditions. This level of produced creatinine is proportional to the muscle mass of the person. The level of creatinine in the urine for adults is 15 to $25 \mathrm{mg}$ per day. Determining the level of urine creatinine is used to diagnose kidney and muscle diseases, and its estimation can determine the extent of kidney injury (Alissio et al., 1985; Rieh et al., 2004). The gamma-glutamyl transferase is a gamma glutamyl cycle enzyme involved in glutathione and 
degradation and restoration (Nemesanzkj et al., 1985). The highest activity of this enzyme is seen in the kidney tissue, which is mainly located on the luminal surface of the epithelial cell membrane. It seems that gamma-glutamyl transferase plays an important role in plasma glutathione excretion (Tate et al., 1985; Zie et al., 1980). Gamma-glutamyl transferase is one of the kidney enzymes located mainly on the luminal surface of the proximal membrane of the tubular epithelial cells. To measure gamma-glutamyl transferase, Pars test kit manufactured by Iran and BT3000 device were used. There has not been much research on kidney disorders in exercise so far. Much research has not been conducted on the kidney disorders in exercise so far. Obviously, the results of such studies can provide useful guidelines for trainers and coaches to plan the type of physical activity, intensity and duration of activity, nutrition and dietary supplements, antioxidants, fluid and electrolyte intake during exercise and before and after the match. Thus, given the importance of kidney tissue, it seems to be necessary to conduct research in order to identify the factors affecting the increase of the mentioned variables, each of which somehow indicates some injuries to the kidney tissue. In the present article, it was aimed to compare urinary protein, creatinine and gamma-glutamyl transferase concentrations as indicators for prognosis of some of the kidney injuries in Iranian football Premier League players who were under pressure of exercises and matches and performed two high-intensity exercises during the week.

\section{Methodology}

The present study aimed to compare the level of changes in urinary excretion of protein, creatinine, and gamma-glutamyl transferase 24 hours before and immediately after one session of acute exercise. Therefore, the research method in this quasi-experimental study was an applied method. The research population included all players in the Iranian Premier League. In the present study, due to the difficulties in coordinating with the football teams competing in the Premier League and considering the goals of the researcher, a total of 30 players in the Iranian Football League in different positions (goalkeeper, defender, midfielder, and forward) were selected as samples of the study using convenient sampling method. The independent variable included high-intensity exercises of teams (aerobic exercise with $85-75 \%$ of maximal oxygen consumption for 30 minutes and anaerobic exercises including lactic exercises such as $30-40 \mathrm{~m}, 200 \mathrm{~m}, 300 \mathrm{~m}$ sprints, and explosive exercises, in which the heart rate is above 170 beats per minute and the exercises lasts for 30 minutes). The characteristics of the exercises have been presented in the protocol section of each exercise. The dependent variables in this study included changes in urine protein, creatinine, and gamma-glutamyl transferase levels. First, players' height and weight were measured. Then, their body mass index (BMI) (squared height (m)/weight $(\mathrm{kg})=\mathrm{BMI}$ ) was calculated to ensure that players' height and weight were measured. The weight of players was measured three times during the day and the average of them was recorded. To measure the height of the subjects, a height meter with a precision of $0.5 \mathrm{~cm}$ was used. To measure the weight of subjects, the SECA220 balance scale with a precision of $0.5 \mathrm{~kg}$ was used. After recording the height and weight of the subjects, their body mass index was also calculated and recorded. The maximal aerobic power test was performed using the Bruce protocol on the treadmill. The Bruce Test or the Bruce Protocol is one of the most commonly used tests for assessing the ability of the cardiovascular system. It was developed by Bruce in 1973 and used widely in medicine under the title of "exercise testing for assessing the heart health." The tool was a treadmill with adjustable slope and speed and timer. The Bruce test is performed on a treadmill and has seven stages. At the beginning of the test, the person usually walks on the treadmill and he or she starts walking fast by increasing the slope and speed from third to fourth stages. The, he or she starts running if be able to continue. Each stage of the Bruce test takes 3 minutes. Table 1 shows the slope and speed of the treadmill. In the Bruce Maximal test, it is rare for a person to continue to work until the sixth and seventh stages, and only endurance runners show such an ability. The activity stops when the person becomes very tired and unable to continue it. Finally, activity time and heart rates are recorded. The maximal oxygen uptake rate is $\mathrm{ml} / \mathrm{kg}$ of body weight per minute.

Table 1. Slope and speed in Bruce Maximal Test

\begin{tabular}{lllll}
\hline stage* & Slope (\%) & Miles/h & Km/h & Speed $/$ min \\
\hline 1 & 10 & 7.1 & 7.2 & 45 \\
2 & 12 & 5.2 & 4 & 67 \\
3 & 14 & 4.3 & 5.5 & 92 \\
4 & 16 & 2.4 & 8.6 & 113 \\
5 & 18 & 5 & 8 & 133 \\
6 & 20 & 5.5 & 8.8 & 147 \\
\hline
\end{tabular}


7

According to an amendment made by Shepherd in 1985, the Bruce sub-maximal test was designed to stop activity when the subject's heart rate reached 150 beats per minute. Usually, an athlete stops in the third or fourth stage and a non-athlete stops at the end of the second or third stage. The exercise protocol consists of 7 to 10 minutes of general exercise, warm-up and stretching exercises, and 30 minutes of aerobic running (on track) with 75 to $85 \%$ of maximal oxygen consumption followed by 40 minutes of high-intensity anaerobic exercises, including lactic exercises such as 30 to $40 \mathrm{~m}, 200 \mathrm{~m}, 300 \mathrm{~m}$ sprints and explosive exercises at a rate above 170 beats per minute. It should be noted that 30 players were measured by pulse counter to determine the intensity of the heart rate exercise. Finally, the players will play 40 minutes of high-pressure football on standard football field.

Table 2. Football players' exercise program

\begin{tabular}{ll}
\hline Type of exercise & Duration of exercise \\
\hline Warm-up (general exercises and stretching exercises) & $7-10 \mathrm{~min}$ \\
Aerobic exercises (aerobic Running with 85-75\% maximal oxygen consumption) & $30 \mathrm{~min}$ \\
anaerobic exercises, including lactic exercises such as 30 to $40 \mathrm{~m}, 200 \mathrm{~m}, 300-\mathrm{m}$ sprints and explosive exercises & $40 \mathrm{~min}$ \\
Play football & $35 \mathrm{~min}$ \\
\hline
\end{tabular}

The urine sample of players have been collected in two stages. In the first stage, players' urine sample was taken after 24 hours without doing exercise. In the second stage, it was taken immediately after exercise. High-intensive exercise causes hemodynamic changes in the kidney and increases protein excretion (Poortmans, 1994). This increase in protein excretion returns to normal level 24 to 48 hours after exercising. At each stage, the players were asked to excrete some of their urine and then their urine was collected in a tube used specifically for sampling. To measure the creatinine gamma-glutamyl transferase and urinary protein of athletes before and after the exercise session, the Pars Azmoon Kit (manufactured by Iran) and 3000 BT device were used. The laboratory methods used to measure creatinine, protein, and GGT were Jaffe, sedimentary and enzymatic, respectively. After completing the sampling and presenting the results of the urine test by the laboratory, the information obtained for statistical analysis were recorded in SPSS software. After collection of data, they were entered into SPSS, version 15 , software. They were analyzed at descriptive and inferential levels. At descriptive levels, indicators such as mean deviation was used. In the inferential statistics section, to test hypotheses and especially to compare changes in urinary gamma-glutamyl transferase before and after exercise and to compare protein, creatinine, and gamma-glutamyl transferase levels between different positions, ANOVA test was used. To use these statistical methods, the data heuristic analysis was first performed to determine outliers and finite values. Then, Kolmogorov-Smirnov test was utilized to examine the normality of the data distribution. Moreover, for pairwise comparison of scores of variables in different positions, LSD post hoc test was used. Minimum level of significance was considered 0.05 in testing the relevant hypotheses and the statistical power of acceptance was considered $80 \%$.

\section{Results}

Mean concentration of proteinuria, creatinine and gamma-glutamyl transferase enzyme excretion are assessed before and after exercise in general. Then, based on different playing positions ANOVA test and post-test LSD test results were used.

Table 3. Physical and physiological characteristics of the subjects

\begin{tabular}{llllll}
\hline $\mathrm{n}$ & Age (year) & Height $(\mathrm{cm})$ & Weight $(\mathrm{kg})$ & BMI $(\mathrm{kg} / \mathrm{m} 2)$ & Aerobic power $(\mathrm{mm} / \mathrm{kg} / \mathrm{min})$ \\
\hline 30 & $80.3 \pm 1.26$ & $39.01 \pm 7.180$ & $26.6 \pm 9.78$ & $13.87 \pm 1.24$ & $77.08 \pm 2.49$ \\
\hline
\end{tabular}

Table 3 presents the mean and standard deviation of age, height, weight, body mass index and maximal aerobic power of the players. The subjects of the study were 22 football players who voluntarily participated in the study. The members of the sample group in this study had a mean age (26.1 \pm 3.80$)$, a mean height (180.01 \pm 7.39$)$, a mean weight $(78.6 \pm 9.26)$ and a mean body mass index $(24.87 \pm 1.13)$ and a maximal aerobic power 49.08 
\pm 2.80. All subjects had good health and did not report any disease. Based on the significance level of Kolmogorov-Smirnov test, data of all the variables of physiological and biochemical characteristics had a normal distribution. Therefore, parametric tests can be used for analyzing the data.

Table 4. Kolmogorov-Smirnov test results in the studied variables

\begin{tabular}{lll}
\hline variable & Kolmogorov-Smirnov test & significance \\
\hline Proteinuria & 777.0 & 58.0 \\
Creatinine & 743.0 & 64.0 \\
gamma-glutamyl transferase & 509.0 & 96.0 \\
\hline
\end{tabular}

Table 4 compares the level of urinary protein concentration before and after acute exercise using ANOVA test.

Table 5. Intra-group effects` comparison test of urinary protein variable before and after acute exercise

\begin{tabular}{llllllll}
\hline Statistical test & $\begin{array}{l}\text { Sum of squares } \\
\text { the third type }\end{array}$ & df & Mean squares & Coefficient f & significance & squares & Statistical power \\
\hline Urinary protein & 669.5203 & 1 & 669.5203 & 909.143 & 001.0 & 770.0 & 00.1 \\
error & 856.1554 & 43 & 159.361 & & & & \\
\hline
\end{tabular}

Table 5 shows the intra-group effects in the variable of urinary protein before and after acute exercise using a standard univariate test $(\mathrm{p}>0.05)$. The level of effect of acute exercise on urinary protein has been shown in first row of Table 4-3. 0.770 of total variance of urine protein in subjects was due to the effect of acute exercise. The statistical power in testing this hypothesis was 0.001 and the discriminative power of significant differences in this analysis was $100 \%$.

Table 6. Intragroup effects` comparison test of urinary creatinine variable before and after acute exercise

\begin{tabular}{llllllll}
\hline Statistical test & $\begin{array}{l}\text { Sum of squares } \\
\text { the third type }\end{array}$ & df & Mean squares & Coefficient $\mathrm{f}$ & significance & squares & Statistical power \\
\hline urinary creatinine & 636.2795 & 1 & 191.5958 & 064.161 & 001.0 & 789.0 & 00.1 \\
error & 364.746 & 43 & 357.17 & & & \\
\hline
\end{tabular}

Table 7. Intragroup effects' comparison test of gamma-glutamyl transferase variable before and after acute exercise

\begin{tabular}{|c|c|c|c|c|c|c|c|}
\hline Statistical test & $\begin{array}{l}\text { Sum of squares } \\
\text { the third type }\end{array}$ & $\mathrm{df}$ & Mean squares & Coefficient $\mathrm{f}$ & significance & squares & Statistical power \\
\hline gamma-glutamyl transferase & 416.90 & 1 & 416.90 & 002.78 & 001.0 & 645.0 & 00.1 \\
\hline error & 841.49 & 43 & 59.1 & & & & \\
\hline
\end{tabular}

Table 8. Mean and standard deviation of urinary protein before and after exercise separately for different positions

\begin{tabular}{lllll}
\hline Variable & position & $\mathrm{n}$ & mean & SD \\
\hline & Defender & 7 & 27.59 & 28.17 \\
Protein before exercise & Midfielder & 8 & 17.70 & 63.14 \\
& forward & 9 & 13.56 & 39.10 \\
& Goalkeeper & 6 & 46.53 & 25.8 \\
& total & 30 & 71.60 & 67.14 \\
Protein after exercise & Defender & 7 & 18.78 & 91.16 \\
& Midfielder & 8 & 10.91 & 93.13 \\
& forward & 9 & 40.64 & 02.7 \\
& Goalkeeper & 6 & 67.64 & 50.6 \\
\hline
\end{tabular}


The real effect of acute exercise on urinary gamma-glutamyl transferase has been presented in the first row of the table above, which was equal to 0.645 in this variable. It means that $0.64 \%$ of the variance of urinary gamma-glutamyl transferase in subjects was due to the effect of acute exercise. The statistical power in testing this hypothesis was 0.001 and the discriminative power of significant differences in this analysis was $100 \%$.

Based on the findings, the protein excretion in midfielders seemed to be higher than that in other positions at both times. The level of real effect before and after acute exercise on urinary protein was 0.344 , meaning that $34 \%$ of the total variance of urinary protein levels among the subjects of different positions was due to the effect of acute exercise. The statistical power in testing this hypothesis was 0.968 and the significant discriminative power of this analysis was 0.97 . In general, the results are as follows:

1. There was a significant difference between different positions in terms of urinary protein before and after exercise $(\mathrm{p}<0.001)$,

2. There was only a significant difference between midfield position and other positions in terms of urinary protein in post-test.

Table 9. LSD post-hoc test for the comparison of urinary protein in different positions

\begin{tabular}{lccc}
\hline & Compared positions & & Mean significant difference \\
\hline Midfielder & Defender & 0.02 & -11.91 \\
Defender & Midfielder & 0.02 & 11.91 \\
& Midfielder & 0.001 & 20.37 \\
Forward & Goalkeeper & 0.001 & 21.57 \\
& Forward & 0.001 & -20.37 \\
Midfielder & goalkeeper & 0.001 & -21.57 \\
Midfielder & &
\end{tabular}

There was only a significant difference between the midfielder and other positions in terms of urine protein $(p<0.05)$. Results showed that urinary creatinine was significantly different in different positions. The real effect of pre- and post-acute exercise on urinary creatinine in the chi-square has been shown in first row of table, which was equal to 0.355 in this variable. It means that $36 \%$ of the total variance in urinary creatinine levels among the subjects of different positions was due to the effect of acute exercises. The statistical power of testing this hypothesis was 0.975 and the discriminative power of significant differences in this analysis was 0.98 . In general, the results showed that there was a significant difference between urinary creatinine before and after exercises $(\mathrm{p}<0.01)$. A significant difference was seen only between goalkeeper and other positions and between midfielder and forward in post-test in terms of urine creatinine $(\mathrm{p}<0.05)$. The results showed that only the goalkeeper showed significant difference with other positions and midfielder and forward showed significant difference with other positions in post-test in terms of creatinine level $(\mathrm{p}<0.05)$.

Table 10. Mean and standard deviation of urinary gamma-glutamyl transferase before and after exercise separately for different positions

\begin{tabular}{|c|c|c|c|c|}
\hline variable & position & $\mathrm{n}$ & mean & $\mathrm{SD}$ \\
\hline \multirow{5}{*}{ Creatinine before exercise } & defender & 7 & 4.72 & 1.43 \\
\hline & midfielder & 8 & 4.31 & 10.02 \\
\hline & forward & 9 & 4.23 & 0.91 \\
\hline & goalkeeper & 6 & 4.66 & 1.00 \\
\hline & total & 30 & 4.46 & 1.06 \\
\hline \multirow{5}{*}{ Creatinine after exercise } & defender & 7 & 6.27 & 2.24 \\
\hline & midfielder & 8 & 5.98 & 1.50 \\
\hline & forward & 9 & 5.95 & 1.11 \\
\hline & goalkeeper & 6 & 8.71 & 1.24 \\
\hline & total & 30 & 6.48 & 1.85 \\
\hline
\end{tabular}

The real effect of pre and post-acute exercise on urinary gamma-glutamyl transferase was 0.185 . It means that $18 \%$ of the total variance in the urine creatinine level of the subjects in different positions was due to the effect of acute exercises. The statistical power of testing this hypothesis was 0.669 and the discriminative power of 
significant differences in this analysis was 0.67 . In general, there was a significant difference between urinary gamma-glutamyl transferase before and after in different positions. Only urinary gamma-glutamyl transferase of the goalkeeper position showed a significant difference with that of other position in the post-test $(p<0.05)$.

Table 11. LSD post-hoc test for comparison of urinary gamma-glutamyl transferase at different positions

\begin{tabular}{lclc}
\hline & Compared positions & & Mean Significant Difference \\
\hline Goalkeeper & Defender & 0.046 & -1.91 \\
Goalkeeper & Midfielder & 0.01 & -1.54 \\
Goalkeeper & Midfielder & 0.009 & -1.59 \\
Defender & & 0.046 & 1.19 \\
Midfielder & Goalkeeper & 0.01 & 1.54 \\
Forward & & 0.009 & 1.59 \\
\hline
\end{tabular}

Only a significant difference was observed between the urinary gamma -glutamyl transferase in goalkeeper position and that of other positions in the post-test $(\mathrm{p}<0.05)$.

Table 12. The significant results of the present study

\begin{tabular}{lcl}
\hline & Significant level & Result (x=significance) \\
\hline Proteinuria & $p \leq 0 / 001$ & $\mathrm{x}$ \\
Urinary creatinine & $p \leq 0 / 001$ & $\mathrm{x}$ \\
Gamma-glutamyl transferase & $p \leq 0 / 001$ & $\mathrm{x}$ \\
Proteinuria in positions & $p \leq 0 / 001$ & $\mathrm{x}$ \\
Creatinine in different positions & $p \leq 0 / 001$ & $\mathrm{x}$ \\
Gamma-glutamyl transferase & $p \leq 0 / 04$ & $\mathrm{x}$ \\
\hline
\end{tabular}

\section{Discussion and Conclusion}

Although it has been stated that exercise has good effects on people's health, research has shown in recent years that professional exercise and consequently high-intensive and continues exercise can cause problems for professional athletes. Repeated high-intensity exercise sessions, decreased kidney blood flow, inadequate recovery, dehydration, and blows imposed to athletes are some of the factors that can cause kidney tissue injury in professional athletes. Kidney tissue injury is associated with physiological symptoms.

These physiological indicators change based on the exercise pressures. The kidneys are responsible for the cleansing of some of the waste substances and toxins resulting from metabolism. Kidney function tests evaluate the ability of the kidneys to excrete these substances. The concentration of certain substances in the blood and urine is often measured to assess the kidney excretion power. Changes in urinary excretion of protein, creatinine and gamma-glutamyl transferase enzymes play a major role in the prognosis of kidney tissue injury.

The hypotheses of the present study included:

1-There is a significant difference between proteinuria levels before and after acute exercise.

2-There is a significant difference between creatinine levels before and after acute exercise.

3-There is a significant difference between the levels of gamma-glutamyl transferase before and after acute exercise.

4-There is a significant difference between the levels of gamma glutamyl transferase, creatinine and urinary protein in different positions.To test the hypotheses, 30 Iranian Premier League football players were selected purposefully using convenient sampling method. Variables of body height, weight, body mass index, maximal aerobic power and urinary protein concentration, urinary creatinine and gamma-glutamyl transferase enzyme were measured on the rest day after exercising ( 24 hours without exercise) and immediately after exercise, the urinary sample of the players was collected. To test the hypotheses and discover significant relationships, especially to compare changes in the levels of protein, creatinine, and gamma-glutamyl transferase before and after exercise and compare the level of excretion of protein, creatinine, gamma- glutamyl transferase between the different positions, ANOVA test was used. Moreover, LSD post hoc test was used for pairwise comparison of the variables. 
The results in general and separately for research objectives showed that:

1- A significant difference was seen between the results of proteinuria excretion before and after the exercise $P \leq 0 / 001$

2- A significant difference was seen between the results of creatinine excretion before and after exercise $P \leq 0 / 001$

3- A significant difference was seen between the results of gamma-glutamyl transferase excretion before and after exercise $P \leq 0 / 001$

4- A significant difference was seen between the results of level of protein excretion in different positions $P \leq 0 / 001$

5-There was a significant difference between the results of creatinine excretion in different positions $P \leq 0 / 001$

6- There was a significant difference between the results of gamma-glutamyl transferase excretion in different positions $P \leq 0 / 04$

By comparing the consistent and inconsistent results in the present study, it was aimed to investigate the effect of one session of acute exercise on the level of changes in concentration of urinary gamma-glutamyl transferase, creatinine, and protein as indicators for the prognosis of some kidney injuries in Iranian Primer Football League players who were under pressure of exercises and competitions and played two heavy games during the week. In order to achieve this goal, specific factors were used as indicators of kidney function during physical activity. These indicators include proteinuria, urinary creatinine, and urinary gamma-glutamyl transferase. Results of the studies conducted in recent years have shown that professional exercise and consequently repetition of high-intensity sessions may lead into kidney tissue dysfunction in professional athletes. In such conditions, urinary proteinuria, creatinine, and gamma-glutamyl transferase (GGT) enzymes are non-invasive and are available tests for assessing kidney injury (Poortmans, 1985; Ayka, 2006). With regard to research hypotheses, the results of this study showed that there was a significant difference between the levels of protein excretion after exercise compared to before exercise. Results showed that $70-80 \%$ of athletes were affected by proteinuria after exercise. Proteinuria was observed not only in collision sports such as football, boxing, but also in non-collision sports such as running, swimming and sailing.

Ayka et al. (2006) investigated the effects of exercise on the level of proteinuria excretion and evaluated the effects of exercise on kidney function in male and female volleyball players. Their results showed that there was a significant difference between the proteinuria levels in males before and after exercising. In their study, Poortmans and Labiloy (1988) investigated the urinary excretion of total protein and albumin and its relationship with running distances. The study was conducted on 15 male runners at $100 \mathrm{~m}, 400 \mathrm{~m}$ and $3000 \mathrm{~m}$ sprints. The results showed that total proteinuria excretion of $330,1640,565 \mu \mathrm{g} / \mathrm{min}$ after $100 \mathrm{~m}, 400 \mathrm{~m}, 300 \mathrm{~m}$ sprints, respectively, was significantly higher than its normal value $(70 \mu \mathrm{g} / \mathrm{min})$. This study also showed a significant correlation (0.85) between blood lactic acid and albumin and total protein excretion after exercise.

It indicated that the intensity of activity had a greater effect on urinary protein excretion compared to the duration of exercise and there was a linear relationship between the intensity of activity and urinary protein excretion. This mechanism has not yet been clarified. Results of the present study with regard to proteinuria were in line with those of previous studies conducted by Ayka (2006), Ayka (2008), Turgut (2003), Grath (2000), Yaguchi (1998), Robert Shaw (1993), Poortmans (1991), Hiai (1990), Poortmans (1989), Ironing (1986), Poortmans (1978). In their study, they found that proteinuria increased as a result of physical activity. In their research, Poprtmans and Van Clock (1978) measured the levels of total protein, micro-albumin B2 in the urine of 15 healthy women before and after high-intensity and short-term exercise. A significant increase was observed in the level of urinary excretion of total albumin, albumin B2, and micro-albumin. This research revealed that the level of variety of proteins returned to their initial levels 45 minutes after the end of exercise.

However, albumin, albumin B2, and micro-albumin levels were still high. Turgut et al. (2003) in their study investigated the acute effect of exercise on the level of protein excretion in children. For this purpose, they examined 13 girls and 14 boys with an age range of 10 to 13 years who were members of the volleyball team in their school. Urinary samples were collected before and 2 hours after doing exercise. The results showed that there was a significant increase in urinary protein concentration in boys and girls after exercise. Based on the conducted studies, glomerular - tubular type of proteinuria excretion increases during short - term and high-intensity exercises and this increase in protein excretion results in an increase in glomerular permeability and a violation in single tubular reabsorption of plasma proteins. This phenomenon can occur immediately and 
transiently in functional disorders of glomerular and tubular nephrons in children after doing exercise.

Poortmans et al. (1989) investigated 13 men under the high-intensity cycling exercise to determine the level of proteinuria during recovery. Total protein and albumin excretion levels were 581 and $315 \mu \mathrm{g} / \mathrm{min}$, respectively, which increased to 42 and $15 \mathrm{~g} / \mathrm{min}$, respectively after doing exercise. However, urinary albumin and protein were elevated 2 hours after exercise. Urinary protein and albumin were still high 2 hours after doing exercise. Total protein and urinary albumin after exercise showed a logarithmic reduction of 54 minutes with the same life and it needed 4 hours to return to rest state level. This study showed a longer period to return initial state in protein control by the kidney compared to other biochemical parameters and provided accurate information on proteinuria kinetics after exercise. Senturk et al. (2007) showed that total protein levels before antioxidant administration in the athlete and non-athlete group $30 \mathrm{~min}$ and $24 \mathrm{~h}$ after exercise showed significant increase compared to steady state. Even with the consumption of antioxidants, total protein increased significantly 30 minutes after doing exercise. As the result of the study showed, it seems that exercise at the championship level and performing continuous activities to obtain fitness during a season may cause disabilities and affect the performance of athletes due to physiological and biochemical changes. In such conditions, evaluation of the changes in proteinuria, urinary creatinine, and urinary gamma-glutamyl transferase as the indicators of kidney function during physical activity can be useful. The results of such studies can provide useful guidance for coaches and trainers in planning the type, intensity and duration of exercises, type of nutrition and dietary supplements, use of antioxidants, fluids and electrolytes during and before and after the matches. It seems that the main reason for the increase in creatinine excretion following high-intensity exercise cen be a reduction in phosphocreatine and increased $\mathrm{Pi}$ and creatinine production. In addition, exercise increases the glomerular filtration ratio, as a result, it increases more creatinine passes through the glomerular network, leading to increased creatinine excretion. Results of the present study with regard to urinary creatinine were in line with those of the studies conducted by Ayka (2006), Turgut (2003), Poortmans (1996), Poortmans (1991), Ironing (1986) and Edes (1990), respectively. In line with the present study, they observed that creatinine excretion increased after physical activity. These results were inconsistent with those of the research conducted by Rasm et al. (1974), William (1970), Clerico (1990), and Poortmans (1978). It seems that difference can be due to differences between football field and other sports and differences between Football players and other sports players in terms of physical pressure imposed on athletes and exercise pressures.

Based on the results of the conducted studies, it seems that urinary creatinine excretion changes after exercise and these changes may eventually increase the glomerular filtration ratio and creatinine excretion rate. This increase in the level of creatinine excretion imposes pressure on kidney, and if this condition continues for a long term, it may cause irreparable injury to kidney tissue, leading to reduced filtration ratio. Exercise pressure and 35 minutes of playing high-pressure football in the present study stimulated creatinine. After collecting urinary samples after doing exercise, creatinine was above the normal levels. Therefore, the athletes in this study might be affected by creatinine complications and might experience kidney tissue injury and glomerular network damage. With regard to the third hypothesis of the study, there were few and different studies on the effect of exercise on the level of urinary excretion of gamma-glutamyl transferase before and after doing exercise. Miay and Ogata (1990) conducted a study on 17 high school baseball players. Results showed that physical activity did not increase significantly the ANG excretion level (2006). In a study on 12 male and 12 female volleyball players, Ayka (2006) found that urinary GGT excretion was significantly different only in male spiker players after doing exercise, whereas no significant difference was found in other positions. However, studies showed that exercise pressure increases gamma-glutamyl transferase after doing exercise. Baguchi (1998) examined and compared the rate of excretion of urinary enzymes before and after triple exercise. In a study on 12 male and 12 female volleyball players, Ayka (2006) found that urinary GGT excretion was significantly different only in male spiker players after exercise, whereas no significant difference was found in other positions. Ayka attributed this increase to high-intensity exercise pressure and jumps in spikes. Ayka (2000) also investigated the effects of high collision exercises such as taekwondo on kidney function. The results showed that gamma-glutamyl transferase increased significantly after the collision exercise.

It seems that these differences in the results on the level of excretion of the gamma-glutamyl transferase after exercise can be related to the type of exercise, the intensity and duration of the exercise. Based on the results of previous studies and the results of this study, it seems that gamma-glutamyl transferase can increase significantly in high collision sports such as taekwondo whose time is short as well as heavy exercises that require repetition and high pressure of exercises such as gymnastics. Therefore, exercise pressure and 25 minutes of high-intensity exercise in the present study stimulated gamma-glutamyl transferase. With regard to the fourth hypothesis of the research, the results of the present study showed that there was a significant difference in the level of urinary 
protein excretion in different positions. Ayka et al. (2006) in their research examined the effects of exercise and level of urinary excretion of gamma-glutamyl transferase GGT, protein, and creatinine one hour after exercise. The results showed no significant difference between male and female players in terms of GGT level before and after doing exercise. Significant increase was seen in proteinuria excretion level for males. With regard to significant increase in urine creatinine levels in females as a result of exercise, it was observed that when urinary GGT levels were compared in setters and spikers, a statistical significant difference was found among them. Exercise increased the level of urinary GGT excretion. In this study, GGT showed significant difference only in make spikers. Ayka attributed this increase to the high-intensity exercise pressure and jumps by spikers. There was a significant difference in the level of creatinine excretion between different positions in this study. According to the results of the present study, the highest mean urinary protein excretion was observed in midfield and the highest mean urinary creatinine excretion was seen in midfield among different positions. The highest mean excretion of gamma-glutamyl transferase was observed in the goalkeeper.

Based on the findings of the studies conducted on football and the role of the players in the team and their activities, this result can be predicted. The midfield players are the most active among the players of four positions and they are required to assist the forward players when team attacks and moves forward and go back and assist the defenders when team defends. Thus, they have to travel longer distance during the match. Based on the studies, they travel almost 10-11 km in an official match, leading to an increase in the level of excretion of protein and creatinine. In addition, goalkeepers have long and frequent jumps to the side of the gate and explosive movements, leading to an increase in the levels of gamma-glutamyl transferase (Douglas, 1993).

In addition, as the present study has been designed for all players in general, the difference in creatinine and protein excretion levels in different positions can be attributed to 35 minutes of playing football at the end of exercise. Finally, it can be stated that due to the novelty of the research, completely convincing reason cannot be provided for differences in mean excretion of protein, creatinine, and gamma-glutamyl transferase enzymes among different positions. Finally, this study revealed that the kidneys, as other body organs, are affected by performing exercises at the championship level and performing heavy and continuous activities to gain physical fitness. Moreover, it seems that high-intensity and long-term exercise can increase the urinary creatinine, protein and gamma-glutamyl transferase levels, which can cause irreparable injury to the kidney if this condition continues over the long term. The results of the study also showed that the gamma-glutamyl transferase is more affected by the intensity of exercises and the collision of exercises and competition. Therefore, the use of certain factors such as proteinuria, urinary creatinine, and urinary gamma glutamyl-transferase enzyme can be useful as the indicators of kidney function during physical activity. According to the results of the present study, it is recommended that the present study can be conducted on athletes of other sports and their results can be compared with each other. It is also recommended that the similar studies to be conducted on different age groups in both genders. It is recommended that the similar study to be conducted on female athletes and its results to be compared with those of the present study in order to reveal gender differences. It is also recommended that the similar study to be conducted on athletes in exercise conditions, as this study was conducted in competition conditions. It is recommended that athletes consume electrolyte-containing fluids before, during, and after high-intensity and prolonged activity. It is also recommended for athletes to use antioxidants that contain vitamin $\mathrm{E}, \mathrm{C}$, and $\mathrm{A}$. It is recommended that medical tests can be performed every few months to check the kidney function.

\section{Conflict of interests}

The authors declare that there is no conflict of interests regarding the publication of this paper.

\section{References}

Alissio, L., Bertin, A., Detrorto, A., Toffoletto, F., \& Ghezzi, L. D. (n. d.). Rehabiltty of orieary creatinine as a parameter used to adjust values of biological indietus. Int Archoccup Environ Heatih, (55), 99-106.

Alyea, E. P., \& Parish, H. H. (1958). Renal response to exercise urinary fu Jama, (167), 807-813.

Ayca, B., Agopyan, A., Sener, A., Oba, R., \& Paslirmaci, G. (2008). E Of gam Glutamyl nanafcrase changing in ulinc related to the training? The f rhytbuimc gvm Agrd 7-10. Bietoro of Spon, (25), 244.

Ayca, B., Izettin, F. V., \& Pala, O. (2004). Nefrotik sendromlu ve Henod Schonlein nefritli cocuklarda N-asctil -glukozarminidaz ve digger biyokimya parumetrelerin izlenmesi. Tip Dergisi, (4), 103-110.

Ayca, B., Sener, A., \& Rammnoglu, N. (2000). Teakwondo mvatEsnasmdosporcularm ktrar Ramma -glutamyl transferase Bktivrtelersa incelemnesi. Diramik Sport Bilimteri Dergist, (1), 254-261. 
Ayca, B., Sener, A., Apikoglu, R. S., \& Oba, R. (2006). The effect of exeix On urinary glutamyl transferasc and protein levels of volleytall playm. J Sport Med Phys Fitness, (46), 623-627.

Bangsbo, J., Norregaard, L., \& Thorsoe, F. (1991). Activity Profile of compete Soccer. Can J Sport Sci, (16), 110-116.

Banibbarata, M., Tarkesh, M., \& Rajapurkar, M. (1999). N. Acet Glueosaminidase Alanine Aminopeptidase and Gamma Glutamyl Transfera Well-knoen renal proximal tubular enzymes and could be useful markers of injury. The Journol of Renal Sciences, (2), 95-107.

Banibrate, M., Shashikant, C., Valentine, L., \& Sishir, R. (2004). Enzym Pattetn in early post renal transplant period diagnostic usefulness in G dysfunction. Indian Journal of Clinical Biochedmistry, 2(19), 437-541.

Beygstein, J. M. (1999). A practical approach to protcinuria. Pediatr N, (13), 697-700.

Hrunette, M. G., Chan, M., \& Lebrun, M. A. (1981). Microfluorometric mehc for aikaline phosphase application to the various segments of the neghta. Anat Bnochem, (115), 236-242.

Zaeimi Fard, E., Rezagholi, B., Jalili, D., Zandian, H. (2017). Evaluation of Physical Fitness, Body Composition and Insulin Resistance Index in Girl Adolescent Athletes and Non-Athletes in the Early and Late Puberty. International Journal of Pharmaceutical Research \& Allied Sciences, 6(3), 08-12.

Cianflocco, A. J. (1992). Renal complication of exercise. Clin-sport- med, 11(2), 437-451.

Clerico, A., Giammattei, C., Cecchini, L., Lucchetti, A., Cruschelli, L., Per, G., Gregori, G., \& Giampietro, O. (1990). Exerecise-induced proteinuria in well trained athletes. Clin Chem, (36), 562-564.

Mady, M., Mohamed Hamid Badr, N., Ezzat Obaya, H., Abdel-Aal, N. M. I. (2018). Effect of resisted exercise to both quadriceps and whole-body vibration on muscle mass of lower limbs and optimal health for overweight women. Journal of Advanced Pharmacy Education \& Research, 8(3), 81-87.

Dilena, B. A. (1983). Six method for determination urinary protein con. Chemistry, 29(3), 553-555.

Doagtas, T. (1903). Physiological characteri of elite Soccer Spon. Met, 16(2), 80-90.

Estine, P., Libinc, R., Tetta, C., Pagano, G., \& Cavallo, P. (1992). Urinary cxcreian induccd by exercise effect of a mountain agonistic footrace to from subjocts Recl function and mountain footrace. J Sport Med Phys, 196-200.

Estne, P., Lirbinc, R., Tetta, C., Pagano, G., \& Cavallo, P. (1992). Urinary excretion induced by exercise effect of a mountain agonistic foctrace in stnbjoctr Recal function and mountain footrace. J Sport Med Phys Fur, 196-200.

Geimby, G. (1965).Renal clearances during prolonged supine exercne differet loads. J. Appl physiol, (20), 1294-1298.

Gerth, J., Ou, U., Funfstock, R., Bartsch, R., Keil, E., Schubert, K., Hubide, J., Scheuch, S., \& Stein, G. (2002). The effect of prolonged physical execik a renal function electrolyte balance and muscle cell breakdown. Clin Ne, (57), 425-431.

Grimby, G. (1965). Renal clearances during prolonged supine exerom Dif Loads. J. Appl physiol, (20), 1294-1298.

Hartam, U., \& Meste, R. J. (2003). Training and overtraining markan a selectd sport events. Med Sel Sport Exert, (32), 209-15.

Hartam, U., \& Meste, R. J. (2003). Training and overtraining marken selected sport events. Med Sci Sport Exert, (32), 209-15.

Hcyuistield, S., Afcaga, B. C., McManus, C., Smithy, J., \& Moffitt. (n. d.). Measutement of muscie mass in human validity of the 24 hour urinay Method. Americon Journal of Chinical Nurtltion, (37), 478-94.

Heymsfaeld, S., Arteaga, B. C., MeManus, C., Smithy, J., \& Moffitl Smithy, J., \& Moffitl, S. (1960). Meascrement of muscfe mass in hvman. Validity of the 24- hour urinary crea.

Heymsfeld, S., Arteaga, B. C., McManus, C., Smithy, J., \& Moffitt, St. (1903). Meae Of muscfe mass in human. Validity of the 24- hour urinary cre Deogtas, T. Physiological charactcter I6lic of elite play Sport. Mect, 16(2), 80-90.

Hvutumcn, N. P., Kaar, M. L., Pietilainen, M., Vierikko, P., \& Reinila, M. (1981). Exercise. Induced proteinuria in children and adolescents. Scad Clin lnvest, (41), 583-587. 
Irving, R. A., Noakes, T. D., Raine, R. I., \& Van Zyl Smit, R. (1989). Trasem oliguria with renal tubular dysfunction after a 90Km running Race. Mde Sci Spin Med, (23), 227-232.

J-Scheuch, S., \& Stein, G. (2002). The effect of prolonged physical exe Real function electrolyte balance and muscle cell breakdown. Clin Ne, (57), 427-431.

Jung, K. (1994). Urinary enzymes and low molecular proteins as markers mbular dysfunction. Kidney Lnt, (46), 29-33.

Jung, K., Diego, J., Strobelt, V., Schloz, D., \& Schreiber, G. (1986). Diagnosic significance of some urinary enzymesfor detecting acute rejection crises in ren? Transplant recipients alanine aminopeptidase. Alkakinc phosphatase gamnt glutamyl transferase N-acetyl-B. D-glucosaminidase and lysozyme, Clin, Ch, (32), 1807-1811.

Lawler, J. M., \& Powers, S. K. (1998). Oxidative stress, anlioxidant sla. The contracting chaphragm Cam J Appl Physiol, (23), 23-55.

Lehir, M., Dubac, U. C., \& Schmidt, U. (1979). Quantitative distribute Lysoso-mal hydrolases inj the rat nephron. Histochemistry, (63), 245-251.

Meersman, R. E., \& Wilkeson, J. E. (1982). Judo nephropathy traurna versta trauma. J. Trauma, 22(2), 150-157.

Mitobe, K. (1998). The effect of triathlon on urinary exercise of enz?? And protens, Int Urol Nephrol, (30), 107-112.

Miyai, T., \& Togata, M. (1990).Change in the coneentration of Proteins after physical Exercise. Acta Med Okayama, (44), 263-266.

Nemesanzky, E., \& Lott, J. A. (1985). Gamma-glutamyltransfetase and its enzyms progress and problem. Clin Chem, (31), 797-803.

Neviackas, J. A., \& Bauer, J. H. (1981). Renal function abnormalities induced marathon running. South Med., (74), 1457-1460.

Pccrtmans, J. R., Jourdain, M., Heyters, C., \& Reardon, F. D. (1990). Posterereise prcteinuria in rowets. Can J Sport Sport Sci, (15), 126-130.

Pcterson, P. A., Evrin, P. E., \& Berggard, I. (1969). Differendrat Beta. 2. maeroglobulin, albumin and total protein. J Clinlcal Inuest, (48), 1198.

Pocrmnans, J. R., \& Heneit, A. (1989). The influence of air-cushin Pcst-exencise protcinuria. J Sport Med Phys Fhness, (29), 213-217.

Pocrtman, J. R. (1997). Exercise and renal function. Exerc Sport Sci-Rev, 255-294.

Poornnons, J. R., \& Jeanloz, R. W. (1968). Quantitive immunolog Determination of 12 plasma proteins exceted in human urine collcctcd befone after exercise. J Clin Invest, (47), 386-393.

Poortman, J. R. (1984). Excrcise and renal function. Sport Med, (1), 125-153.

Poortman, J. R., Mathieu, N., \& De Plaen, P. (1996). Infiuence of running dittem distances. Occup Physid, (72), $522-527$.

Poortmans, J. R., \& Labilloy, D. (1988). The influcnce of work intensity Postexercise proteinuria. Eur J Appl Physiol Occup Physiol, (57), 260-261.

Poortmans, J. R., Engels, M. F., Sellier, M., \& Leclercq, R. (1991). Urine-p excretion and swimrning events. Med Sei Sport Exerc, (23), 831-835.

Poortmans, J. R., Rampaer, L., \& Wolra, J. C. (1989). Renal proul after exereise in mon. Eur J Appl Physiol, (58), A76-480.

Poortmans, L. R., \& Vanderstraeten, J. (1994). Kidney fanction during heahhy and chseased bummn. South Med., (18), 419-437.

Poortmns, J. R., Depelchin, P., Vanckrstraceten, J., Deplaen, P., Staroukne, \& Leclercq, R. (1990). Hormonal modulation of postexecise protem Beahhy humans. Mad Sci-Sports, (22), 22-26.

Price, R. G. (1979). Unnary N-acetyl-B-D-glucosaminidase as indicara a renal disease. In U. C. Dubach, \& U. Schrnidt (Eds.), Diagnostic significamce of emye and proteins $m$ anine (pp. 150-163). Bern, Hans Huber Publishers. 
Radac, Z., Asnno, K., Lnouc, M., Kizaki, T., Ohishi, S., Suzuki, \& Tara Ohno, H. (1990). Superoxide dismutase derivative prevents oxsdatine dar Live and kidoey of rates induced by exbausting exetcise. Eur.J Appl, (12), 189-194.

Refsum, H. E., \& Stromme, S. B. (1974). Urea and ereatinine produet Excretion in urine during and after prolonged heavy exercise. Seam Lab Invest, (33), 247-254.

Reilly, T., Atkinson, G., \& Waterhose. (1997). Biologixal Rhythms and EseOxford Medicine Publicotions, 15-27.

Ibrahim S., Azhar A.S., Ather A.S., Ahsan A.S. (2018). Weight Training Protocol: Impact of Diverse and Organized Exercise on Certain Components of Motor Fitness and Functional Variables Amongst Males. International Journal of Pharmaceutical Research\&Allied Sciences, 7(2), 8-14.

Riehl, O., Foniano, K. E., \& Lopez, R. F. (2004). Excecao de creatinine com meio de analise da massa marga corporal. Lecturas Educocion Fieicay Depon (IO), 1-8.

Rowe, D. S., \& Sooth, J. F. (1961). The proteins of postutal and excm prateinria. Clin Sci., (21), 87-91.

Tare, S. S., \& Meister, A. (1958). Garmma-glutamyl transpcptidase Kiohey. In A. Meister (Ed.), Methodw in Enzymology. Academic Press, NO.

Tsuo, B. N., \& Curthoys, P. (1980). The absolute asymmetry of orient Gamma-ghutamyltranspeptidase and amino peptidase on the externd the renal brusb border membrance. J. Biol Chem., (225), 16-25.

Turgut, G., Kaptanoglu, B., Turgut, S., Genc, O., \& Tekintur, S. (n. d.). Intluece of acute exercise on urinary protein Creatinine insulin-like grov?? Ehikdrn. Tohoku J Exp Med, (201), 165-70.

Vanderlinde, R. E. (1981). Urinary enzyme measurements in the diagro Renal disorders Ann. Clin. Lab Sci, (11), 189-201.

Watetlow, J. C., Neale, R. J., Rowe, L., \& Palin, I. (1972). Effect of d Infection on creatinine tumover in the rat. American Journol of Clinical nvtri, (25), 371-375.

William, A., Kachadorian, E., \& Robert, E. (1970). Johnson Renalrespome various rates of exercise. Journal of Applied physiology, (28), 161-170.

Zambraski, E. J., Bober, M. C., Goldstein, J. E., Lakas, C. S., \& Shepard. (1981). Changes in renal cortical sialic acids and colloidal iron stant associated with exercise. Med Sci Sport Exerc, (13), 229-232.

\section{Copyrights}

Copyright for this article is retained by the author(s), with first publication rights granted to the journal.

This is an open-access article distributed under the terms and conditions of the Creative Commons Attribution license (http://creativecommons.org/licenses/by/4.0/). 